\title{
Parental knowledge and participation in the management of children with juvenile idiopathic arthritis at Tripoli children hospital, rheumatology department
}

\author{
Ebtisam.S.khawaja, Mabruka.A.Zletni, Awatif.M.Abushhaiwia \\ Pediatric rheumatology department, Tripoli children hospital ,Tripoli-Libya
}

\section{Introduction:}

-Juvenile idiopathic arthritis(JIA) is the most common rheumatic disease in children and constitute the bulk of pediatric rheumatology clinic patients.

-Parents of a children with JIA face challenges when caring for these children.

-Parents knowledge are important to help in the management of such a chronic disease and to prevent complications.

-Knowledge acquisition is a complex process and depends on teaching style and contents, parents intelligence, level of education and motivation.

\section{objectives:}

$\checkmark$ To investigate parents knowledge about their child's disease. $\checkmark$ To focus on important role of health education in understanding this disease.

$\checkmark$ To establish a future plan for education program to the newly diagnosed patients and a general public health education program.

\section{Patients \& methods:}

-A cross-sectional, descriptive study conducted at rheumatology department, Tripoli Children hospital over 6 months period from January to end of June 2017. A total of 100 parents of children with JIA following in pediatric rheumatology clinic were assessed during their routine clinic visits by using a multiple choice questionnaire.

-The questionnaire addressed 6 main areas: 1)parental knowledge about child's diagnosis, 2)source of information and their satisfaction, 3)general knowledge about definition of arthritis, 4)knowledge regarding medical and physical treatment, 5)knowledge regarding participation in physical activities during school, 6)knowledge regarding vaccination.

-The level of education of parents was divided in to 5 levels:1-illetereate, 2-primary school education,3-secoundary school education,4-university level and, 6-higher.

* The main outcome in this study is the parental awareness about juvenile idiopathic arthritis in children and this was related to parents education using chi square(X2). Data was analyzed using SPSS-16.

\section{Results:}

The knowledge of 100 parents of children with JIA was studied, 94\% were Libyan, 54\% of them came from out side Tripoli. Mean duration of follow up in the rheumatology clinic was $4.4 \pm 0.37$ years, education level of assessed parents in table $1.68 \%$ of participant have no previous knowledge on JIA before diagnosis of their children. Majority ,97\% aware of their child's diagnosis and this was not corresponding to their level of education as $97 \%$ with educational level $4 \& 5$ answered correctly compared with $98.1 \%$ with educational level $1 \& 2(\mathrm{p}=0.10)$
Table 1 parents characteristics

\begin{tabular}{l|l}
\hline Characteristics & NO (\%) \\
\hline $\begin{array}{l}\text { Nationality: } \\
\quad \text { Libyan } \\
\text { Non }\end{array}$ & $94(94 \%)$ \\
$\begin{array}{l}\text { Address } \\
\quad \text { Tripoli } \\
\text { out-side }\end{array}$ & $6(6 \%)$ \\
\hline $\begin{array}{l}\text { Relation to patient } \\
\text { mother } \\
\text { father }\end{array}$ & $46(46 \%)$ \\
$\begin{array}{l}\text { Educational level } \\
\text { 1-illeterate }\end{array}$ & $54(54 \%)$ \\
2-primary school & \\
3- secondary school & $50(50 \%)$ \\
4-university & $50(50 \%)$ \\
5-higher & $10(10 \%)$ \\
\hline
\end{tabular}

Table 2 Source of information and parents satisfaction

\begin{tabular}{|l|l|}
\hline Variable & NO(\%) \\
\hline $\begin{array}{l}\text { Source of information } \\
\text { physician } \\
\text { other source* }\end{array}$ & $\begin{array}{l}72(72 \%) \\
\text { Adequacy of information } \\
\text { satisfactory }\end{array}$ \\
$\begin{array}{l}\text { Not } \\
\text { * Other sources: books, news paper,TV, net work, friends } \\
\text { and family members }\end{array}$ \\
\hline
\end{tabular}

Table 3 parents knowledge about the disease

\begin{tabular}{|l|l}
\hline \multicolumn{1}{|c}{ Character } & $\mathrm{NO}(\%)$ \\
\hline Correct diagnosis & $97(97 \%)$ \\
\hline Definition of arthritis & $51(51 \%)$ \\
\hline Etiology of illness & $63(63 \%)$ \\
\hline JIA can remit spontaneously & $41(41 \%)$ \\
\hline JIA can be cured & $48(48 \%)$ \\
\hline NSAIDS is the main treatment & $68(68 \%)$ \\
\hline Steroid commonly used & $83(83 \%)$ \\
\hline Chemotherapy is used in treatment & $46(46 \%)$ \\
\hline Biological drugs are used in treatment & $52(52 \%)$ \\
\hline Drugs should not be stopped suddenly & $72(72 \%)$ \\
\hline Physiotherapy is important in treatment & $78(78 \%)$ \\
\hline Encourage to participate in school activities & $76(76 \%)$ \\
\hline Child can take all vaccination & $46(46 \%)$ \\
\hline
\end{tabular}

Conclusion: questionnaire is simple way to investigate the parental knowledge regarding JIA, the result shows high level of knowledge in majority of parents of children with JIA compared with low level before starting follow up in rheumatology clinic which indicate need for general public heath education program. 